\title{
Longitudinal study on relapses of leprosy in Polynesian multibacillary patients on dapsone monotherapy between 1946 and 1970
}

\author{
J-L CARTEL, J-P BOUTIN, A SPIEGEL, \\ R PLICHART \& J-F ROUX \\ Institut Territorial de Recherches Medicales Louis Malarde, BP 30 , \\ Papeete Tahiti-Polynesie Francaise
}

Accepted for publication 14 September 1990

\begin{abstract}
Summary Between 1946 and 1970, 295 new leprosy patients were detected in French Polynesia, of whom 145 were multibacillary. Of these 145, put on dapsone monotherapy, 131 reached bacteriological negativity in a period of time ranging from 2 to 12 years (average 4.72 years) and were followed-up for a period of time ranging from 19 to 43 years (median follow-up period after bacteriological negativity: 18 years). Among the 131 patients, 36 relapses were detected, the first one 4 years after bacteriological negativity and the last one 26 years after. The crude relapse rate was $27.5 \%$, the risk of relapse was 1.39 per 100 patient years and the cumulative relapse probability, calculated using the lifetable method, reached $0 \cdot 38 \pm 11$ by year 31 of the study. From these findings one may assume that, at least in French Polynesia, one-third to one-half of multibacillary patients put on dapsone monotherapy would relapse if still present 36 years after bacteriological negativity. Such results re-emphasize the need for leprosy patients to be treated with multidrug therapy as recommended by WHO.
\end{abstract}

\section{Introduction}

Studies on relapse of leprosy in multibacillary patients, either on treatment or after cessation of treatment with sulphone therapy, have been carried out in several countries ${ }^{1-}$ 7,9-11,14,16 with different results. The crude relapse rate ranged from $4 \cdot 5$ to $20 \%$ in patients on treatment ${ }^{1,4}$ and from $4 \cdot 8$ to $45 \cdot 5 \%$ in patients released from treatment ${ }^{2,4,6,10,14,16}$ and the risk of relapse from $4 \cdot 5$ to $6 \cdot 3$ per 100 patient years..$^{3,7,10,11}$ In one study, the cumulative relapse probability varied from 10.6 to $62.4 \%$ according to the type of lepromatous leprosy and to the level of attendance for treatment by the patients. ${ }^{10}$ In a more recent study, ${ }^{5}$ it was $18.9 \%$. For the treatment of leprosy, dapsone monotherapy has been replaced by multidrug therapy but the efficacy of treatment is still assessed on the occurrence of relapse. Accurate knowledge on relapse in patients on dapsone monotherapy as well as those on multidrug therapy is still required to compare the efficacy of different schemes of treatment. The aim of this paper is to report the relapse rate, the risk of relapse, the cumulative relapse probability and the incubation time of relapse observed 
in a retrospective study of 145 patients detected in French Polynesia between 1946 and 1970, put on dapsone monotherapy and followed-up for a median period of time of 18 years after bacteriological negativity.

\section{Materials and methods}

Between 1946 and 1970, 295 new leprosy patients were detected in French Polynesia, of whom 145 were multibacillary, put on dapsone monotherapy, and correspond to the study population. Each year of the study, patients were withdrawn when they fulfilled one of the 3 following exclusion criteria: (i) they were declared 'off register' (according to the OMSLEP system); ${ }^{8}$ (ii) they did not remain on dapsone monotherapy; and (iii) they suffered a relapse (each relapsing patient was excluded the year following the relapse). Each patient entered into the study (starting date or year 0) when he became bacteriologically negative. The closing date of the study was 31 December 1988. For each patient, the trial time was the period of time elapsed between the year he entered into the study and either the year he was withdrawn or the last year of the study (1988).

From 1946 to 1970 the diagnosis of leprosy was based on a clinical examination of the skin and large nerve trunks, supplemented by biological tests: the search for acid-fast bacilli in the nasal mucosa and the skin (earlobes and skin lesions), biopsy for histopathological examination and, since 1951, the lepromin intradermal reaction. For the purpose of this study patients were designated paucibacillary or multibacillary retrospectively, according to the data in the medical records: a leprosy patient was considered as multibacillary when acid-fast bacilli with a bacteriological index $(\mathrm{BI}) \geqslant 2$ were found in at least one of the samples (bacteriological or pathological examination). A relapse was defined as the reappearance of acid-fast bacilli with $\mathrm{BI} \geqslant 2$ in at least one sample, accompanied by clinical signs, in a multibacillary patient who had been negative for 3 years or more. The incubation time of the relapse was defined as the period of time between the moment the patient became bacteriologically negative and the moment the relapse was detected. In 1946, sulphone therapy was the basis of treatment, dapsone was introduced in 1948 and prescribed as a lifelong monotherapy for multibacillary patients. Rifampicin began to be prescribed occasionally from 1970 onwards.

Data analysed in this study comes partly from the central register and partly from the medical records of the patients. They were anonymously computerized according to the OMSLEP system. Statistical analysis was by Student's $t$-test, Pearson's chi-square test and exploratory data analysis. ${ }^{15}$ The cumulative relapse probability was established using lifetable methods. ${ }^{13}$ The $95 \%$ confidence limits of the cumulative relapse probability were calculated using Rothman's formula. ${ }^{12}$

\section{Results}

Of the 145 multibacillary patients put on dapsone monotherapy, 14 were withdrawn from the study population because they died (11 patients) or because they were given rifampicin ( 3 patients) before reaching bacteriological negativity. At year 0 , the study population consisted of 131 bacteriologically negative patients (Table 1) who were followed-up during a median period of time of 18 years after negativity (4-36 years). In them, the 
Table 1. Risk per 100 patient years and cumulative relapse probability in 131 multibacillary patients on dapsone monotherapy followed-up during 36 years

\begin{tabular}{|c|c|c|c|c|c|c|}
\hline \multirow{2}{*}{$\begin{array}{l}\text { Years after } \\
\text { bacteriological } \\
\text { negativation }\end{array}$} & \multicolumn{2}{|c|}{ Multibacillary patient } & \multirow{2}{*}{$\begin{array}{l}\text { No. of } \\
\text { relapses }\end{array}$} & \multirow{2}{*}{$\begin{array}{c}\text { Risk of relapse } \\
\text { per } 100 \\
\text { patient years }\end{array}$} & \multirow{2}{*}{$\begin{array}{l}\text { Cumulative* } \\
\text { relapse } \\
\text { probability } \\
(\%)\end{array}$} & \multirow{2}{*}{$\begin{array}{l}\text { Confidence } \\
\text { limits } \\
(95 \%)\end{array}$} \\
\hline & Included & Withdrawn & & & & \\
\hline 0 & 131 & 0 & 0 & & $0 \cdot 00$ & $(0-3)$ \\
\hline 1 & 131 & 0 & 0 & & $0 \cdot 00$ & $(0-3)$ \\
\hline 2 & 131 & 0 & 0 & & $0 \cdot 00$ & $(0-3)$ \\
\hline 3 & 131 & 0 & 0 & & $0 \cdot 00$ & $(0-3)$ \\
\hline 4 & 131 & 2 & $\overline{1}$ & & $0 \cdot 77$ & $(0-4)$ \\
\hline 5 & 129 & 0 & 0 & $0 \cdot 13$ & $0 \cdot 77$ & $(0-4)$ \\
\hline 6 & 129 & 3 & 1 & & $1 \cdot 54$ & $(0-5)$ \\
\hline 7 & 126 & 3 & 2 & & $3 \cdot 11$ & $(1-8)$ \\
\hline 8 & 123 & 9 & 5 & & $7 \cdot 11$ & $(4-13)$ \\
\hline 9 & 114 & 3 & 1 & & $7 \cdot 94$ & $(4-14)$ \\
\hline 10 & 111 & 5 & 1 & & $8 \cdot 78$ & $(5-15)$ \\
\hline 11 & 106 & 4 & 2 & $1 \cdot 69$ & $10 \cdot 52$ & $(6-17)$ \\
\hline 12 & 102 & 7 & 2 & & $12 \cdot 32$ & $(8-19)$ \\
\hline 13 & 95 & 6 & 3 & & $15 \cdot 13$ & $(10-23)$ \\
\hline 14 & 89 & 7 & 4 & & $19 \cdot 01$ & $(13-27)$ \\
\hline 15 & 82 & 6 & 2 & & $21 \cdot 03$ & $(15-29)$ \\
\hline 16 & 76 & 6 & 1 & & $22 \cdot 11$ & $(15-31)$ \\
\hline 17 & 70 & 5 & 1 & $2 \cdot 53$ & $23 \cdot 25$ & $(16-32)$ \\
\hline 18 & 65 & 2 & 1 & & $24 \cdot 44$ & $(17-33)$ \\
\hline 19 & 63 & 4 & 1 & & 25.67 & $(18-35)$ \\
\hline 20 & 59 & 4 & 3 & & $29 \cdot 48$ & $(21-39)$ \\
\hline 21 & 55 & 6 & $\overline{1}$ & & $30 \cdot 83$ & $(23-41)$ \\
\hline 22 & 49 & 2 & 0 & & $30 \cdot 83$ & $(23-41)$ \\
\hline 23 & 47 & 4 & 1 & $2 \cdot 07$ & $32 \cdot 35$ & $(24-42)$ \\
\hline 24 & 43 & 10 & 2 & & $35 \cdot 82$ & $(26-46)$ \\
\hline 25 & 33 & 4 & 0 & & $35 \cdot 82$ & $(26-46)$ \\
\hline 26 & 29 & 5 & 1 & & $38 \cdot 19$ & $(28-49)$ \\
\hline 27 & 24 & 0 & 0 & & $38 \cdot 19$ & $(28-49)$ \\
\hline 28 & 24 & 0 & 0 & & $38 \cdot 19$ & $(28-49)$ \\
\hline 29 & 24 & 2 & 0 & 1.69 & $38 \cdot 19$ & $(28-49)$ \\
\hline 30 & 22 & 4 & 0 & & $38 \cdot 19$ & $(28-49)$ \\
\hline 31 & 18 & 9 & 0 & & $38 \cdot 19$ & $(28-49)$ \\
\hline 32 & 9 & 3 & 0 & & & \\
\hline 33 & 6 & 2 & 0 & & & \\
\hline 34 & 4 & 2 & 0 & & & \\
\hline 35 & 2 & 0 & 0 & 0.00 & & \\
\hline 36 & 2 & 2 & 0 & & & \\
\hline Total & 2585 & 131 & 36 & $1 \cdot 39$ & $38 \cdot 19$ & $(28-49)$ \\
\hline
\end{tabular}

* Not calculated after year 31 because number of patients is less than 10 .

negativity time (period of time required to achieve bacteriological negativity) ranged from 2 to 12 years (on average 4.72 years), it was significantly higher $(t=2 \cdot 07, P<0.05)$ in the 36 relapsing patients $(5 \cdot 3$ years) than in the 95 nonrelapsing patients $(4 \cdot 5$ years). The number of relapses was 36 , thus giving a crude relapse rate of $27 \cdot 5 \%$. Of the 131 patients, $55(42 \%)$ were females, of the 36 relapsing patients, $14(39 \%)$ were females. The earliest relapse was observed in a patient 4 years after reaching negativity and the latest one 26 years after. The incubation time of relapses ranged between 4 and 8.5 years in 9 of the 36 relapsing patients 


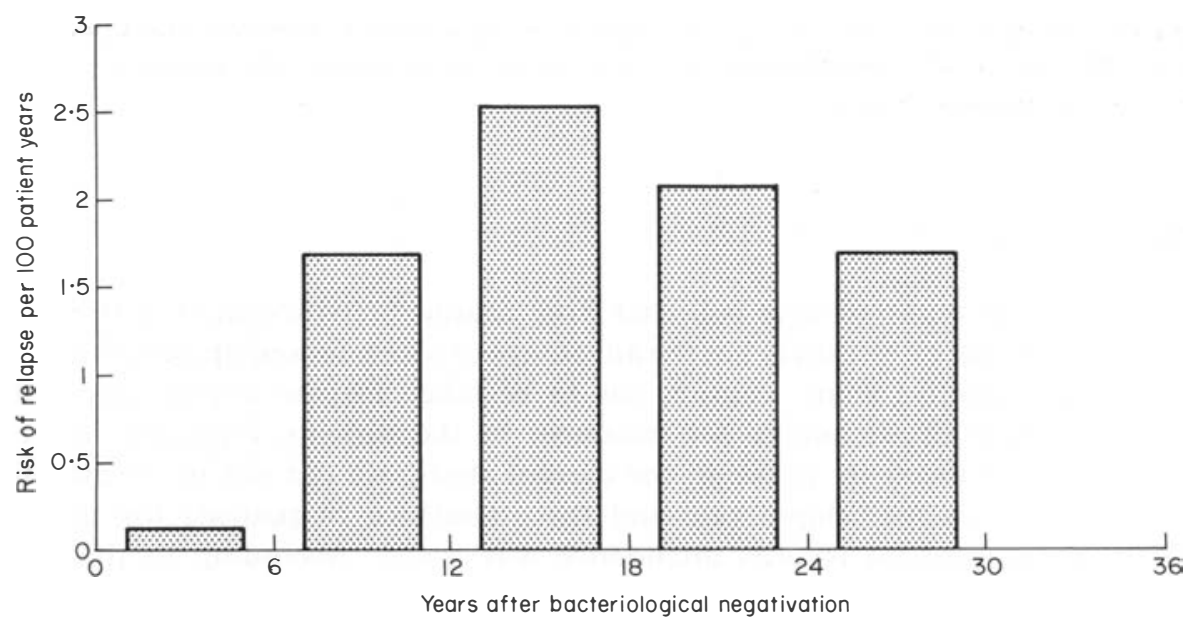

Figure 1. Evolution of the risk of relapse with the passage of time in 131 multibacillary patients on dapsone monotherapy followed-up during 36 years after bacteriological negativity.

$(25 \%)$, between $8 \cdot 5$ and $18 \cdot 5$ years in $18(50 \%)$ and between $18 \cdot 5$ and 26 years in the last 9 $(25 \%)$. The median incubation time was $13 \cdot 5$ years $\pm 2.6(95 \%$ confidence limit $)$.

The cumulative exposed population since year 0 to year 36 was 2585 patient years (Table 1); thus, a number of 36 relapses gives an average risk of relapse of 1.39 per 100 patient years. In order to assess whether a variation was observed with the passage of time during the 36 years of the study, we calculated the risk of relapse on 6 six-year periods of time. It was $0 \cdot 13,1 \cdot 69,2 \cdot 53,2 \cdot 07$ and 1.69 per 100 patient years during the first, second, third, fourth and fifth periods, respectively, and 0 during the sixth and last one (Figure 1). No significant difference was found between the 5 risks of relapse $(p>0.05)$. The cumulative relapse probability (Table 1, Figure 2), which takes into account the patients

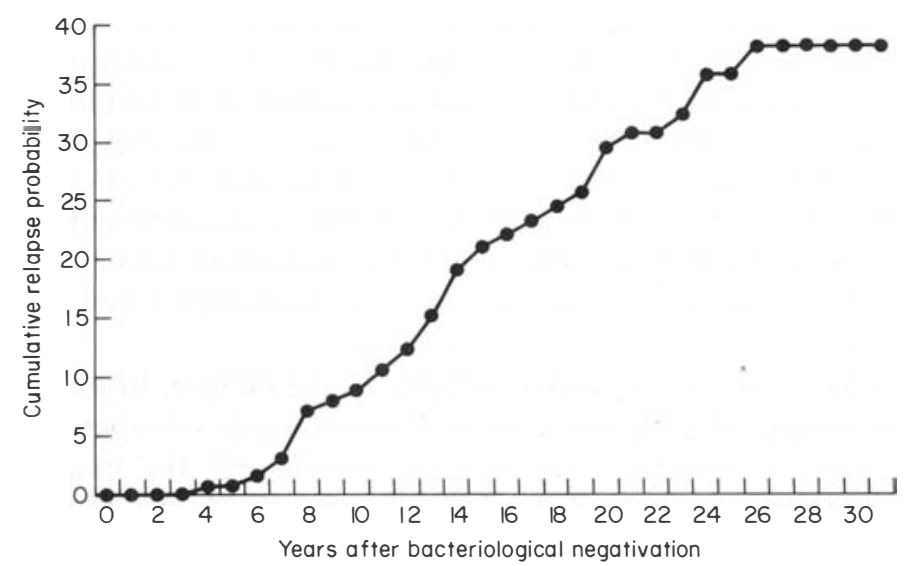

Figure 2. Cumulative relapse probability observed in 131 multibacillary patients followed-up during 31 years after bacteriological negativity. 
withdrawn each year of the study, reached $0.38( \pm 0 \cdot 11)$ on year 31 , the closing date (afterwards, the study population was less than 10 patients, the minimum number required for lifetable evaluation).

\section{Discussion}

The data we have reported were collected from routine activities and not from a predesigned trial; however, the study has the advantage of a long follow-up period. As in any long-term retrospective study, caution has to be taken for the interpretation of the findings. The level of attendance for treatment by the patients, especially in lifelong therapy, is very difficult to assess; in the current study, we did not try to establish a correlation between the relapse rate and the attendance of patients for treatment, although in the medical records attendance was noted. According to the sex, no significant difference $(p>0.05)$ was found between the distribution of the relapses in the relapsing patients group ( $36 \%$ of the relapsing patients were females) and that of the patients in the study population ( $42 \%$ of the patients were females).

A crude relapse rate of $27 \cdot 5 \%$, over a total period of 36 years is not a surprising finding. In a study conducted in Russia, Torsuev et al. ${ }^{14}$ reported the occurrence of 45 cases of clinical and bacteriological relapse among 187 patients followed-up for 18 years, that is a $24 \cdot 1 \%$ crude relapse rate. It must be pointed out that the crude relapse rate gives a simple proportion and does not take into account the patients withdrawn from the study. The 1.39 per 100 patient years risk of relapse observed in our study is not very different from the $1 \cdot 2 \%$ to $3 \cdot 2 \%$ risk reported by other authors. ${ }^{3,7}$ In fact, the use of the risk of relapse is limited by the assumption that the occurrence of relapse is constant and this indicator is not representative of the kinetic of the occurrence of relapse. The cumulative relapse probability is a much more valid indicator because: (i) it allows consideration of all the patients entering into the study, as a single cohort; (ii) it takes into account the withdrawn patients; and (iii) it gives a picture of the occurrence of relapse each year over the whole study period. In our study it was $0 \cdot 38 \pm 0 \cdot 11$, indicating that roughly one-third to one-half of multibacillary patients put on dapsone monotherapy would relapse if still present 36 years after bacteriological negativity. Such a figure needs to be compared with results reported by other authors. By 1970, Quagliato et al. ${ }^{10}$ calculated the cumulative relapse probability (using the lifetable method) in a cohort of 815 multibacillary patients followed-up over 22 years. The cohort was divided into 6 groups according to the severity of disease and the treatment regularity of the patients and overall cumulative relapse probability was not given. Nevertheless, it is reasonable to assume that it might have been similar to that we have reported. In 1989, Kurz et al. reported a lower cumulative relapse probability $(18.9 \%)$ in a cohort of 1886 patients, but the median follow-up period was 10 years only and the confidence limits were not given. ${ }^{5}$

A last important point is the incubation time of the relapse. In the present study, it ranged from 4 to 26 years and was, on median, $13 \cdot 5$ years $\pm 2 \cdot 6$. As shown in Table $1,86 \%$ $(31 / 36)$ of the relapses occurred between the fourth and the twentieth year after bacteriological negativity and the last relapse occurred 26 years after bacteriological negativity. The 13.5 years median incubation time was similar to that reported in a study performed in Guadeloupe, in which $69 \%$ of the relapses occurred between the first and the twentieth year after negativity. ${ }^{3}$ Quagliato et al. reported comparable figures and, because 
the incubation time could be of more than 10 years, he suggested that treatment and follow-up of multibacillary patients on dapsone monotherapy should be continued for life. ${ }^{10}$

\section{Conclusion}

The main conclusions of our study are that: (a) the cumulative relapse probability is the best indicator for evaluation of the efficacy of treatment of leprosy; and (b) the considerable occurrence of relapse in multibacillary patients on dapsone monotherapy reemphasizes the necessity for leprosy patients to be put on multidrug therapy as recommended by WHO. ${ }^{17}$

\section{References}

1 Basto P, Barbosa A. The effect of sulphone therapy in achieving bacillary negativity. Abstract 210 of the Ninth International Leprosy Congress, London. In Int J Lepr, 1968; 36: 657.

2 Browne SG. Relapse in leprosy. Uzuakoli settlement, 1958-1964. Int J Lepr, 1965; 33: 273-79.

${ }^{3}$ Cartel J-L, Naudillon Y, Remy J-C, Grosset J-H. Contribution of relapses to total infection sources of leprosy in Guadeloupe. Lepr Rev, 1987; 58: 339-48.

${ }^{4}$ Erickson PT. Relapses following apparent arrest of leprosy by sulphone therapy. Pub Hlth rep, 1950; 65: 1147-57. Reprinted in Int J Lepr, 1951; 15: 309-15.

${ }^{5}$ Kurz MX, Declercq EE, Vellut $\mathrm{CH}$. Rate and time distribution of relapses in multibacillary leprosy. Int $J$ Lepr, 1989, 57: 599-606.

6 Lowe TJ. The chemotherapy of leprosy. Late results of treatment with sulphone and with thiosemicarbazone. Lancet, 1954; 2: 1065-8. Reprinted in Int J Lepr, 1955; 23: 181-91.

7 Noordeen SK. Relapse in lepromatous leprosy. Lepr Rev, 1971; 42: 43-8.

8 OMSLEP, système d'enregistrement et de notification des malades de la lèpre. Unité d'Épidémiologie. Université Catholique de Louvain. Publié en collaboration avec l'OMS. Genève 1981.

9 Price RB. Relapse of leprosy in American Samoa. Amer J Trop Med Hyg, 1959; 8: 358-63.

10 Quagliato R, Bechelli LM, Marques RM. Bacterial negativity and reactivation (relapse) of lepromatous outpatients under sulfone treatment. Int J Lepr, 1970; 38: 250-63.

11 Rodriguez JN. Relapses after sulfone therapy in leprosy of the lepromatous type. Int J Le pr, 1958; 26: $305-12$.

12 Rothman KJ. Estimation of confidence limits for the cumulative probability of survival in life table analysis. J Chron Dis, 1978; 31: 557-60.

13 Schwartz D, Flamant R, Lelouch J. L'essai thérapeutique chez l'homme. 2nd ed, Flammarion, Paris, 1981.

14 Torsuev NA, Bogun VV, Sokolo VV, Karabadjakov KK. The problem of relapses in leprosy patients. Voprosy Leprol. i Dermatol. (Rostov on Don) 19; 1965. Abstract in Int J Lepr, 1965; 33: 922.

15 Velleman PF, Hoaglin DC in $A B C$ of $E D A$, pp. 65-73. Ed Duxburry Press. Boston, USA. 1981.

16 Waters MFR, Rees RJW, Laing ABG, Khoo Kah Fah, Meade TW, Parikshak N, North WRS. The rate of relapse in lepromatous leprosy following completion of twenty years of supervised sulphone therapy. Lepr Rev, 1986; 57: 101-9.

17 WHO Study Group. Chemotherapy of leprosy for control programmes. Technical report series No. 675, 1982. 


\title{
Étude longitudinale de rechutes de lèpre chez des patients multibacillaires de la Polinésie soumis à un traitement de monotérapie de dapsone, 1946-70
}

\author{
J-L Cartel, J-P Boutin, A Spiegel, R Plichart et J-F Roux
}

Sommaire 295cas nouveaux de lèpre ont été détectés en Polinésie française entre 1946 et 1970, dont 145 ont été du type multibacillaire. Dans le cas de ces derniers 145, mis sous un traitement de monothérapie de dapsone, 131 ont atteint négativité bactériologique dans une période de temps comprise entre 2 et 12 ans (moyen de 4,72 ans). Ils ont continué sous observation pour une période de temps comprise entre 19 et 43 ans (période médiane d'observation après avoir atteint négativité bactériologique: 18 ans). 36 rechutes ont été détectées entre ces 131 patients, dont la première 4 ans et la dernière 26 ans après avoir atteint négativité bactériologique. Le taux brut de rechute a été de $27,5 \%$, le risque de rechute de 1,39 par 100 années-patient et la probabilité accumulée de rechute, calculée par la méthode 'lifetable', avait atteint $0,38 \pm 11$ par l'année 31 de l'étude. A partir de ces résultats, on peut bien supposer que, au moins en Polinésie française, entre un tiers et la moitié des patients multibacillaires qui auraient suivi un traitement de monothérapie de dapsone auraient souffert une rechute s'ils étaient encore en vie 36 ans après avoir atteint négativité bactériologique. Tels résultats soulignent encore le besoin de traiter d'une thérapie à drogues multiples aux patients de lèpre suivant les récommendations de la OMS.

\section{Estudio longitudinal sobre las recaídas en pacientes de lepra polinesios con infecciónes de múltiples bacilos tratados por monoterapia de dapsona}

\author{
J-L Cartel, J-P Boutin, A Spiegel, R Plichart y J-F Roux
}

Resumen Entre 1946 y 1970 se detectaron en la Polinesia francesa 295 nuevos casos de lepra, entre los cuales 145 fueron causados por infección de múltiples bacilos. De estos 145 , que fueron sometidos a una monoterapia de dapsona, 131 alcanzaron negatividad bacteriológica al cabo de un periodo de tiempo de 2 a 12 años (con una media de 4,72 años). Siguieron bajo observación durante un periodo de tiempo entre 19 y 43 años (periodo mediano de observación tras negatividad bacteriológica: 18 años). Entre estos 131 pacientes, se detectaron 36 recaídas, la primera de estas 4 años después de alcanzar negatividad bacteriológica y la última 26 años después. La frecuencia bruta de recaída fué de un $27,5 \%$, el riesgo de recaída de 1,39 por cada 100 años-paciente y la probabilidad acumulada de recaída, calculada por el método de 'lifetable', alcanzó el $0,38 \pm 11$ para el trigésimoprimer año del estudio. A partir de estos descubrimientos, se puede deducir que, al menos en la Polinesia francesa, entre un tercio y la mitad de los pacientes de infecciones multiples de bacilos sometidos a una monoterapia de dapsona aún con vida 36 años despues de alcanzar negatividad bacteriológica sufririan una recaída. Estos resultados vuelven a subrayar la necesidad de someter a los pacientes de lepra a una terapia de drogas múltiples según recomienda la OMS. 